\title{
Complex C1-2 osteophyte presenting with severe dysphagia and ptosis
}

Puya Alikhani, MD, Yazan Suradi, MD, Sheyar Amin, MD, and Ushtar Amin, MD

Neurology ${ }^{\circledR}$ 2020;94:324-325. doi:10.1212/WNL.0000000000008969
Correspondence

Dr. Amin

uamin@usf.edu

Figure 1 Brain MRI and neck CT scan show a large C1-2 complex osteophyte
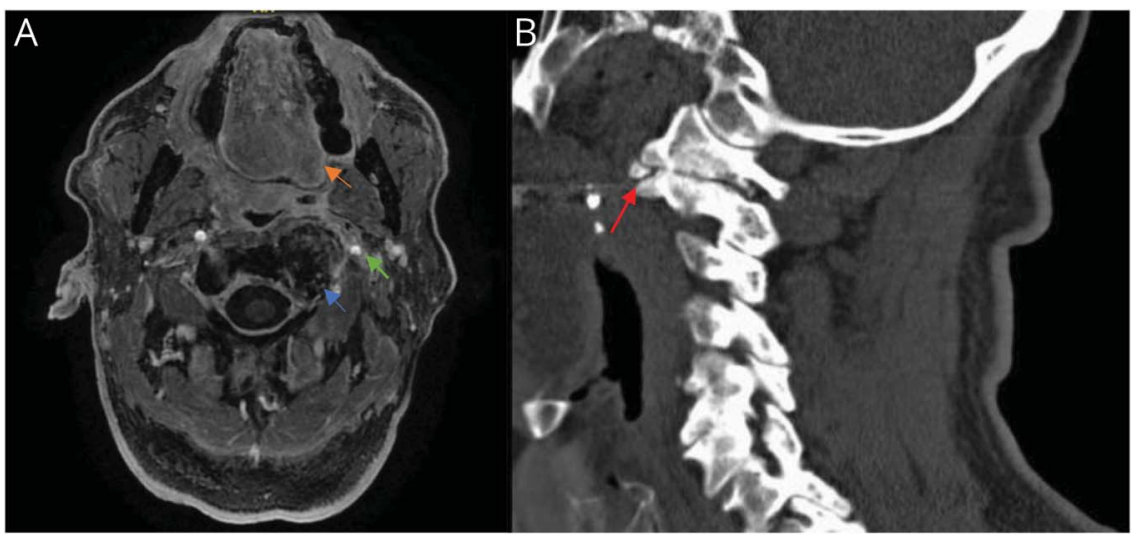

(A) Axial postcontrast brain MRI. The blue arrow points to the large C1-2 complex osteophyte, the green arrow shows displaced carotid sheath, and the orange arrow shows left hemitongue atrophy. (B) Sagittal CT scan of the neck. The red arrow points to the C1-2 complex osteophyte.

Figure 2 Preoperative and postoperative head CT

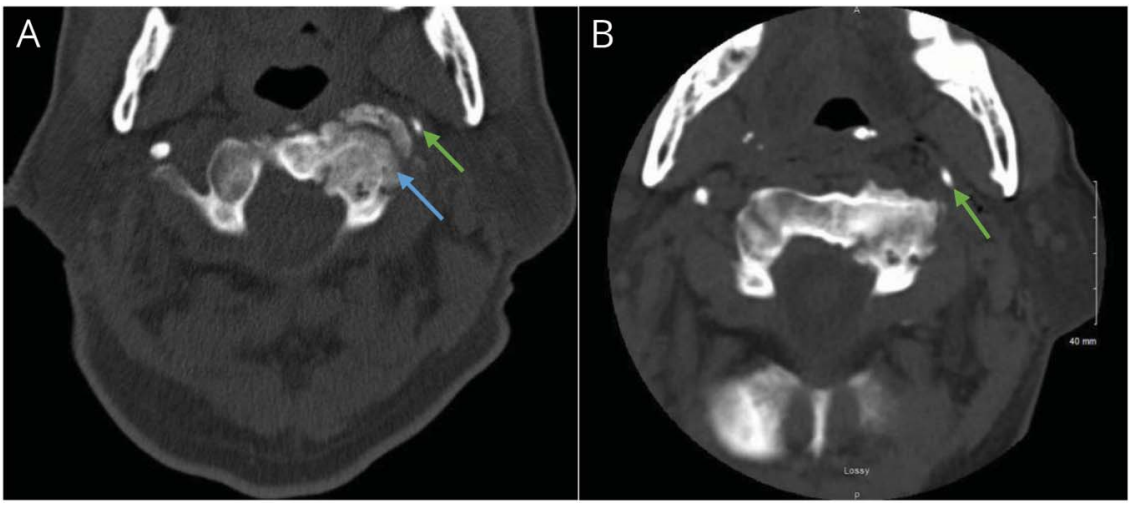

(A) Axial head CT. The blue arrow points to the C1-2 complex osteophyte and the green arrow points to the displaced left carotid sheath. (B) Axial CT head postoperatively shows decompressed carotid sheath (green arrow).

A 67-year-old man presented with dysphagia, hoarseness, dysarthria, left ptosis, and 30-pound weight loss over 7 months, requiring a percutaneous endoscopic gastrostomy (PEG) tube. Examination revealed partial left ptosis, dysphonia, left hemitongue weakness, atrophy, and fasciculations, and left hemipalate weakness (figure 1).

Neurosurgery was consulted for high cervical osteophyte resection. Intraoperatively, the left carotid sheath and hypoglossal nerve were impinged by C1-2 osteophyte (figure $2 \mathrm{~A}$ ). The osteophyte was resected (figure $2 \mathrm{~B}) .{ }^{1,2}$

From the University of South Florida, Tampa.

Go to Neurology.org/N for full disclosures. Funding information and disclosures deemed relevant by the authors, if any, are provided at the end of the article. 
On 1-month follow-up, the patient had gained 20 pounds, his voice had returned to normal, and the ptosis had resolved. The PEG tube was removed and the patient resumed a normal diet.

\section{Study funding}

No targeted funding reported.

\section{Disclosure}

The authors report no disclosures relevant to the manuscript. Go to Neurology.org/N for full disclosures.

\begin{tabular}{llll}
\multicolumn{2}{l}{ Appendix } & Authors \\
\hline Name & Location & Role & Contributions \\
\hline $\begin{array}{l}\text { Puya } \\
\text { Alikhani, } \\
\text { MD }\end{array}$ & $\begin{array}{l}\text { University of } \\
\text { South Florida, } \\
\text { Tampa }\end{array}$ & Author & $\begin{array}{l}\text { Diagnosed the patient and } \\
\text { performed the surgery, } \\
\text { provided preoperative and } \\
\text { postoperative images, helped } \\
\text { draft the manuscript }\end{array}$ \\
\hline
\end{tabular}

Appendix (continued)

\begin{tabular}{|c|c|c|c|}
\hline Name & Location & Role & Contributions \\
\hline $\begin{array}{l}\text { Yazan } \\
\text { Suradi, } \\
\text { MD }\end{array}$ & $\begin{array}{l}\text { University of } \\
\text { South Florida, } \\
\text { Tampa }\end{array}$ & Author & Revised the manuscript \\
\hline $\begin{array}{l}\text { Sheyar } \\
\text { Amin, } \\
\text { MD }\end{array}$ & $\begin{array}{l}\text { University of } \\
\text { South Florida, } \\
\text { Tampa }\end{array}$ & Author & Revised the manuscript \\
\hline $\begin{array}{l}\text { Ushtar } \\
\text { Amin, } \\
\text { MD }\end{array}$ & $\begin{array}{l}\text { University of } \\
\text { South Florida, } \\
\text { Tampa }\end{array}$ & Author & $\begin{array}{l}\text { Drafted the manuscript and } \\
\text { edited the images }\end{array}$ \\
\hline
\end{tabular}

\section{References}

1. Jabarkheel R, Chen YR, Xu L, et al. Transoral endoscopic resection of high cervical osteophytes with long-term symptoms resolution: case series, imaging, and literature. World Neurosurg 2018;120:240-243.

2. Erdure O, Tasli H, Polat B, et al. Surgical management of dysphagia due to anterior cervical osteophyte. J Craniofac Surg 2017;28:80-84.

\section{Pre-order Annual Meeting On Demand and Save \$150+}

Save $\$ 150+$ when you pre-order 2020 Annual Meeting On Demand by May 1. This comprehensive, CME-accredited digital library of presentations from the 2020 AAN Annual Meeting gives you ready access to 500 hours of content and syllabi from more than 200 top-tier programs - from the convenience of your home or office! Order yours now at AAN.com/view/20AMOD.

\section{Sign Up for the AAN's Axon Registry}

The AAN encourages its US members to show their interest in participating in the Axon Registry by signing up today.

Use the Axon Registry to:

- Simplify reporting requirements under MACRA's Quality Payment Program and avoid penalties while reducing your administrative burden

- Meet your MOC Part IV requirements and waive up to eight credits of Part II Self-Assessment

- Choose from 22 AAN neurology-specific quality measures that fit your practice

- Use data to understand your practice and identify where improvements can be made to patient care

- Manage your patients at a population level; look at a specific group of patients based on conditions, risk factors, demographics or outcome

- Demonstrate your value to payers when negotiating reimbursement

- Enjoy multi-year, fee-free access when you sign the agreements and integrate your EHR with the registry

Learn more at AAN.com/view/Axon and send your questions to registry@aan.com. 


\section{Neurology}

\section{Complex C1-2 osteophyte presenting with severe dysphagia and ptosis}

Puya Alikhani, Yazan Suradi, Sheyar Amin, et al.

Neurology 2020;94;324-325 Published Online before print January 21, 2020

DOI 10.1212/WNL.0000000000008969

This information is current as of January 21, 2020

Updated Information \& Services

References

Subspecialty Collections

Permissions \& Licensing

Reprints including high resolution figures, can be found at: http://n.neurology.org/content/94/7/324.full

This article cites 2 articles, 0 of which you can access for free at: http://n.neurology.org/content/94/7/324.full\#ref-list-1

This article, along with others on similar topics, appears in the following collection(s):

All Spinal Cord

http://n.neurology.org/cgi/collection/all_spinal_cord Cranial neuropathy

http://n.neurology.org/cgi/collection/cranial_neuropathy CT

http://n.neurology.org/cgi/collection/ct

MRI

http://n.neurology.org/cgi/collection/mri

Information about reproducing this article in parts (figures,tables) or in its entirety can be found online at:

http://www.neurology.org/about/about_the_journal\#permissions

Information about ordering reprints can be found online:

http://n.neurology.org/subscribers/advertise

Neurology ${ }^{\circledR}$ is the official journal of the American Academy of Neurology. Published continuously since 1951, it is now a weekly with 48 issues per year. Copyright @ 2020 American Academy of Neurology. All rights reserved. Print ISSN: 0028-3878. Online ISSN: 1526-632X.

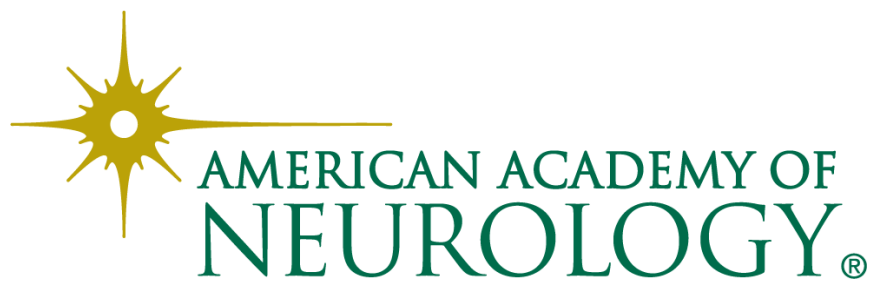

